Journal of Development and Communication Studies

Vol. 5. No. 1, July 2016 - June 2017 ISSN (Online \& Print): 2305-7432. http://www.devcomsjournalmw.org.

\title{
Uses, benefits and challenges of using rural community telecentres as tools for development: the Case of Vikwa Community Telecentre in Kasungu, Malawi
}

\author{
Sellina Khumbo Kapondera, Lecturer \& Head, Department of Library and \\ Information Services, Mzuzu University, Mzuzu, Malawi, Email: \\ skapondera@gmail.com $\mathcal{E}$
}

Dave Mankhokwe Namusanya, Community, Youth Development and Development Communication Consultant, Blantyre, Malawi. Email: dnamusanya@gmail.com

\begin{abstract}
This paper examines the uses, benefits and challenges of using telecentres as tools for development in Malawi focusing on one community telecentre: Vikwa Community Telecentre in the Kasungu district of Malawi. Quantitative and qualitative data were gathered using a questionnaire administered to 46 users; interviews with the Telecentre Manager; and observation of the categories of people coming to the telecentres; what they were using and challenges sues and challenges within the telecentre. The findings indicate that the users are improving their skills and knowledge, school performance, finding new friends and saving money. The community uses the telecentre to improve work related skills, keep in touch with friends and families and look for jobs. The negative finding is that telecentre usage is uneven as users are generally poor male youths with little education. Furthermore, the users face a number of challenges when using the telecentre. For the telecentre to have more impact on development, the paper recommends that the Vikwa Telecentre should work on attracting all groups of people in the community, change the internet service provider, buy an electricity generator, acquire more books and computers and train staff in customer care.
\end{abstract}

Key words: development, telecentres, Malawi, multipurpose community telecentres, Vikwa Community Telecentre.

To cite this article: Kapondera, S.K. \& Namusanya, D. M.(2017). Uses, benefits and challenges of using rural community telecentres as tools for development: the Case of Vikwa Community Telecentre in Kasungu, Malawi. Journal of Development and Communication Studies, 5(1): 1-21. https://dx.doi.org/10.4314/jdcs.v5i1.1 


\section{Introduction}

Information and Communication Technologies (ICTs) are critical tools for development and bridging the digital divide (Garrido, Sey, Hart \& Snatana, 2012; Lashgarara, Karimi \& Mirdamadi, 2012; Bailey, 2009; Soriano, 2007). This is due to the fact that ICTs create new economic and social opportunities worldwide (Lwoga \& Chigona, 2016). For example, with access to ICTs farmers can increase their incomes by helping farmers regularly check prices and easily communicate with buyers (Kenny, 2002) and there is an increase in social interaction and sharing of ideas among people (Buhigiro, 2012; Chikumba, 2010). As such, many developing countries are engaging in various efforts to make ICTs available to many. One of the most common ways through which this is being achieved is the establishment of telecentres, which offer public access to ICTs for educational, personal, social and economic development (Harris, Kumar \& Balaji, 2003). Many developing countries are establishing these facilities in rural areas. This is mainly attributed to the fact that in many developing countries, the large percentage of the population lives in rural areas where individual access to ICTs and information is limited (Gcora, Gopen, Tuswa, Lwoga \& Chigona, 2015; Islam \& Hasan, 2009). Their income levels are also low mostly depending on agriculture, fishing and small-scale businesses (Isaacs, 2007; Rose, 1999). Therefore, in these communities, telecentres are established aiming at empowering citizens and improving the social and economic development of the areas (Bailey, 2009; Islam \& Hasan, 2009). Telecentres are being considered as tools for development for the numerous roles that they play in the field of development. For example, telecentres bring the benefits of ICTs closer to rural areas thereby helping them save money. Telecentres also provide space for rural community members to interact and share ideas on various issues important to their lives and improve computer and internet skills of the communities as an end in themselves (Buhigiro 2012; Lashgarara et al., 2012).

As noted above, the idea behind establishing telecentres is to provide shared access to ICTs and develop rural communities by bringing the benefits of ICTs closer to them. These objectives can only be achieved if the communities surrounding the telecentres use and benefit from the facilities. Although the assumption of establishing telecentres is that is that all community members will adopt and use them (Kapondera \& Hart, 2016), their presence in the communities does not automatically lead to usage and their usage does not translate into benefits (Warschauer, 2003). Therefore, it is important to investigate how the communities use telecentres and benefit from such facilities to understand their effectiveness (Soriano, 2007). As such, this study aimed at exploring the uses, benefits and challenges of using the telecentres as tools for rural community development in Malawi where studies of such a nature are limited. 


\section{Telecentres in Malawi}

The study was conducted at Vikwa Telecentre in Kasungu District, Central Malawi whose detailed information is provided in the next section. Malawi is a developing country, which at the time of the study ranked at 173 out of 185 countries on Human Development Index (Human Development Report 2015, p. 210). It had a projected population of about 15 million people, more than half of whom lived below the poverty line of $\$ 1$ a day (Malawi Government, 2014). According to the Human Development Report (2015, p. 236), close to $84 \%$ of the population lives in rural areas; and $90 \%$ of the rural dwellers rely on agriculture (Isaacs, 2007) which, mostly gives the rural dwellers low incomes and the incomes are seasonal (IFAD 2014). Access to Information and Communication Technology (ICT) services in Malawi is low. According to the Malawi Communications Regulatory Authority (2015), its 2014 national survey on ICT services established that $42 \%$ of the households in the rural areas have, at least, a mobile phone; only 3.4 $\%$ of the households have access to the internet. The survey further established that only $30.6 \%$ of individuals in the rural areas have a mobile phone and only $23.5 \%$ own a phone that is capable of browsing the internet; $2.1 \%$ of the people in rural areas used a computer while $2.9 \%$ of the population was understood to use the internet. Table 1 summarises these statics.

Table 1: Levels of ICT penetration in rural areas in Malawi

\begin{tabular}{|l|l|}
\hline Type of ICT & Percentage \\
\hline Mobile phones (households) & 42 \\
\hline Internet (households) & 3.4 \\
\hline Mobile phones (individuals) & 30.6 \\
\hline Smart phones (individuals) & 23.5 \\
\hline Access to computers & 2.9 \\
\hline & \\
\hline
\end{tabular}

Due to the insufficient ICT infrastructure that leads to a digital divide in the country, in the early 2000s Malawi embarked on a project to establish telecentres to bring the benefits of ICTs to rural areas. Specifically, the multipurpose community telecentres, which are the focus of this study, were established in order to bridge the digital divide through provision of universal access to ICTs that are offered within the centres which are located within the rural communities (Kayira, 2013; Chikumba, 2010; Gondwe, 2008). Just as in many developing countries, telecentres in Malawi exist in different models all aiming at bringing the benefits of ICTs to disadvantaged communities. Currently, there are more than 50 telecentres in different models. For example, some telecentres are housed in post offices which are run by the Malawi Post Corporation (Chikumba 2010). There are also multipurpose community telecentres which are normally located in rural areas. These, in addition to ICT services 
common in post office telecentres, they contain a component of a library (Kapondera \& Hart, 2016). Some of telecentres are run and managed by individual while others are managed by communities. There are three community managed multipurpose telecentres in the country (Banda, 2016), one of which is the subject of this study.

\section{Vikwa Community Telecentre}

The study targeted Vikwa Community Telecentre situated approximately 25 kilometres East from Kasungu Municipality, effectively being placed in a remote area where access to things such as electricity and clean water is difficult. It is a perfect example of a rural area in Malawi.

The telecentre is located in Mphepo Village of Traditional Authority (T/A) Wimbe in Kasungu District of Malawi. The total population in its catchment area is 180,000 people. The catchment area is surrounded by eight secondary schools, over 30 primary schools, three health care centres. The telecentre also serves people from outside the catchment area like Kasungu Municipality. Many people in this area are tobacco farmers. The main services offered at the telecentre include: Internet, printing, photocopy, book binding, lamination, colour printing, library, ID design and printing, Airtel money, Kiosk (a tuck shop), Computer Training and Scanning. The telecentre was opened in May 2010 (Njinga, 2016). The telecentre was chosen for two reasons. Firstly, the telecentre is the oldest community managed multipurpose telecentre. The choice of the community managed telecentres was pertinent because communities have an influence on adoption and usage of telecentres (Kapondera \& Hart, 2016). Secondly, among the three-multipurpose community managed telecentres, it is the one with the widest usage base in the country (Banda, 2016) thereby being the one that has the highest contribution towards objectives of the study using the technique of purposive sampling (Guarte \& Barrios, 2006).

\section{Overview of telecentres}

Telecentres are facilities that offer public access to ICTs for educational, personal, social and economic development (Harris et al., 2003; Harris, 2001). They are mainly established to provide benefits of ICTs in rural and marginalized areas where individuals cannot afford to have ICTs (Mbangala \& Sumzigi, 2014; Lashgarara et al., 2012; Ariyabandu, 2009). Telecentres are known by different names. They are called Rural Knowledge Centres, Information Kiosks, Village Knowledge Centres, Thusong Service Centres and Multipurpose Community Telecentres (MCTs) all of them aiming at offering shared access to ICTs (Mukerji, 2008; Owen \& Darkwa, 2000). There exist different kinds of telecentres ranging from micro telecentres that are usually housed in a shop providing access to payphones with built-in web browser, a smart card reader and a receipt printer to a full service telecentre that offers 
access on a range of services that include many phone lines, multi-media computers with Internet connectivity, colour as well as black and white printers, photocopiers, a scanner, a digital camera, a video camera, television, overhead projector, laminator, meeting and video conferencing room (Jensen \& Esterhuysen, 2001). MCTs offer different services to different groups within the communities that they serve. Their services mainly include telephone, fax, e-mail, Internet access, word processing and photocopy, training on the use of these technologies and library (Islam \& Hasan, 2009; Jensen \& Esterhuysen, 2001; Rose, 1999). Telecentres may be established by individuals or by governments as projects of national agency. As such, their ownership differs. Some of them are run by individuals while some, like MCTs are managed by communities (Dahalin, Yusop, Ibrahim, Kasiran, \& Mat, 2009; Jensen \& Esterhuysen, 2001). Despite the different models that exist, all telecentres aim at providing public venues which are open to all categories of people in the communities and offer access to ICTs services at low costs (Jensen \& Esterhuysen, 2001).

\section{Users and uses of telecentres}

Research on telecentre users and uses places much emphasis on the categories of people using the telecentres and purposes for using them. Literature shows that generally, most users are males, young and with average incomes (Neville, 2012; Chigona, Lekwane, Westcott, \& Chigona, 2011; Dahalin et al., 2009).

However, having many people with low income levels as users of telecentres is a good development since telecentres target the disadvantaged communities where individuals cannot afford ICTs (Mbangala \& Samzugi, 2014; Islam \& Hasan, 2009). There are mixed findings on educational levels of users. While some studies reveal that most users are educated (Neville, 2012; Chigona et al., 2011; Dahalin et al., 2009), others have established that telecentres are used by the less educated because the community served by these telecentres have very few people with tertiary qualifications (Kapondera \& Hart, 2016; Lashgarara et al., 2012).

Telecentre users visit and use telecentres and their services for different purposes. Some community members use telecentres for social purposes; educational purposes (Mbatha, 2015; Chigona et al., 2011; Bailey, 2009). Others visit the telecentres to seek jobs online; and to look for job advertisements in newspapers. Some community members, especially farmers, use the telecentres to access information on market prices on various agricultural products; and access information on best farming practices (Buhigiro, 2012). News, Sports and entertainment are also accessed in telecentres (Chigona et al., 2011). 


\section{Challenges that telecentre users face}

Telecentre users face many challenges. Inadequacy of facilities is a common problem that telecentre users face. Some telecentres do not have enough computers and in the context of developing countries, the Internet connection is usually bad and slow (Gcora et al., 2015; Hassan Yusof, Seman, \& Sheik, 2010). Another challenge that telecentre users face is that telecentres are usually operational for a few hours in a day (Hassan et al., 2010). This might be attributed to the fact that most telecentres keep formal government working hours. Some other challenges include shortage of staff (Gcora et al., 2015), lack of materials in local languages within the centre, poor staff attitude (Mtega \& Malekani, 2009); and complexity and cost of using some services like the Internet (Buhigiro, 2012). In countries where electricity is also an issue, like Malawi is (Taulo, Gondwe, \& Sebitosi, 2015), the power cuts are also a serious challenge to the users of telecentres. If telecentres are to be successful, there is a need to address the challenges because they negatively affect the use and effectiveness of telecentres.

\section{Methodology}

Quantitative and qualitative data were collected from users and the telecentre Manager using a questionnaire and interview respectively; also, there was observation done at the telecentre. Forty-six (46) users who came to use the telecentre during the data collection period of three days in February 2016 were given a questionnaire that contained both open ended and close-ended questions also known as semi-structured questionnaire. Semi-structured questionnaires were used because the inclusion of open ended questions allowed respondents to write their own opinions and allowed the researchers to obtain answers that were not anticipated when they were formulating the questionnaires (Mathers, Fox, \& Hunn, 2007; Reja, Manfreda, Hlebec, \& Vehovar, 2003). Users were given questionnaires to ensure uniformity of the questions given to all the users which in turn contributed to reliability of data (Fowler, 2009). Face to face interview was conducted with the telecentre Manager.

The researchers used face to face interview with the telecentre Manager as it allowed to observe the surrounding and ask the manager questions based on the observations. The interview with the manager focused on the types of people using the telecentre; and views of the Manager on how the telecentre benefits the community Observations on age and gender of users and telecentres frequently used; and challenges in the use of the telecentres were also conducted within the telecentre by one of the researchers during the data collection period. Observations were conducted because they allow to observe things that participants would be unwilling to share related to the topic under study and record events as they occur in the natural setting (DeWalt \& DeWalt, 2002; Kawulish, 2005). 
The researchers adopted a mixed methods approach because it minimized problems that occur with the use of a single method approach (Bryman cited in Mwiinga \& Hamooya, 2016; Onwuezbuzie \& Jonson, 2006) and that the diverse types of data best provided an understanding of the research problem (Creswell, 2003). For example, interviews with the manager only to understand the benefits of using the telecentres would have provided responses based on his perspective and not the actual users. Therefore, getting the views from users as well enriched data.

Quantitative data were using descriptive statistics using Microsoft Excel. On the other hand, qualitative data were analysed using thematic analysis techniques, which involved transcribing data, searching for themes, reviewing and finally refining the theme to avoid duplication of the themes (Braun \& Clarke, 2006). Due to ethical consideration, users are identified by codes. The codes composed of prefix QR (for questionnaire respondent) followed by sequential number. For example, users number one and two were identified as QR1 and QR2 respectively.

\section{Results and Discussions}

This section presents the findings of the study on the following themes: Vikwa telecentre users and its uses; benefits of using Vikwa Telecentre and Challenges that Vikwa Telecentre users face.

\section{Telecentre users and its uses}

This study aimed at finding out the demographic composition of people using the telecentre focusing on their age and gender; their educational qualifications; their occupation; and, income levels. We also found out the duration of their use of the telecentre; the frequency of use of the telecentre; and, the purposes for which they use the telecentre. The findings on this are discussed below.

\section{Demographics of Vikwa Telecentre users}

This section investigated the demographics of users in terms of gender, age, occupation, income levels and highest qualification levels of users. Table 2 summarizes the findings.

\section{Age and Gender}

Respondents were asked to indicate their age. The youngest respondent was 11 and the oldest was 38 years old. The mean age was 22 and the standard deviation was 5.95. Observations during the data collection period also confirmed that youths dominate usage of the Telecentre. Similarly, previous studies in literature on age of ICT public access venues (e.g. (Mbangala \& Samzugi, 2014; Neville, 2012; Chigona et al., 2011; Dahalin et al., 2009) also found that youths dominated the usage of the facilities. 
The majority of the users (63 percent), were males. This finding agrees with the findings of other studies in literature which also found more males than females used telecentres (Mbangala \& Samzugi, 2014; Neville, 2012; Chigona et al., 2011). Understanding what leads to a few women using the telecentres is important because this disparity could continue widening the already existing digital divide which telecentres aim to bridge.

Table 2: Demographic information aboutVikwa Telecentre users

\begin{tabular}{|c|c|c|c|}
\hline & & $\begin{array}{l}\text { Number of } \\
\text { respondents }\end{array}$ & Percentage \\
\hline \multirow[t]{2}{*}{ Gender } & Male & 29 & 63 \\
\hline & Female & 17 & 37 \\
\hline \multirow{5}{*}{$\begin{array}{l}\text { Highest } \\
\text { qualification }\end{array}$} & Primary school qualification & 3 & 7 \\
\hline & $\begin{array}{l}\text { Junior secondary school } \\
\text { qualification }\end{array}$ & 7 & 15 \\
\hline & $\begin{array}{l}\text { Senior secondary school } \\
\text { qualification }\end{array}$ & 31 & 67 \\
\hline & Tertiary qualification & 4 & 9 \\
\hline & Adult education & 1 & 2 \\
\hline \multirow[t]{4}{*}{ Occupation } & Business personnel & 13 & 32 \\
\hline & Farmers & 3 & 7 \\
\hline & Students & 22 & 52 \\
\hline & Teachers & 3 & 7 \\
\hline \multirow[t]{5}{*}{ Income levels } & Below K5,000/month & 21 & 52 \\
\hline & K5,000-K10,000/month & 8 & 20 \\
\hline & K10,001-K25,000/month & 5 & 13 \\
\hline & K25,001-K50,000/month & 2 & 5 \\
\hline & Above K50,000/month & 4 & 10 \\
\hline
\end{tabular}

Educational qualifications of Vikwa Telecentre users

From Table 2, the highest educational qualification of users is senior secondary school qualification 31 (67\%), Malawi School Certificate of Education (MSCE) which one obtains after passing senior secondary school exams. Observations revealed that majority of these respondents came to the Telecentre to read because they were still in secondary school to improve their grades having not performed well during their first attempt as evident in the following comments made by one of the users:

"I use the telecentre for studies. I passed my MSCE exams with 27 points though I am repeating. I know I will do better because the telecentre is a good place for studies" Questionnaire Repondent (QR) 14 


\section{Vikwa Telecentre users' occupation}

In terms of the occupation for users at Vikwa Telecentre, only 41 users indicated their occupation. As depicted in Table 2, the majority of users (22.54) were students; business people were next with (13.32) respondents identifying themselves as business people. There were also $3(7 \%)$ farmers and $3(7 \%)$ teachers. The students' dominance may be attributed to the fact that most schools in Malawi, including the ones where the telecentre is located, do not have libraries; and that Vikwa telecentre, which has a library, provides conducive environment for reading as evident in the following comments made by the telecentre Manager:

"And most of the students, as we are surrounded by schools, have got an access to the library here only."

Of the forty people who responded to the question on income levels, (21.52) earn below K5,000/month which, based on the 2016 average exchange rate of $\$ 1$ to MK707.295 is below $\$ 7.07$ a month.; 8 people (20\%) indicated that they earn between $\mathrm{K} 5,000$ and $\mathrm{K} 10,000$ a month. Table 2 also shows that 5(13\%) earn between K10001 and K25000; that 2(5\%) earn between K25001 and K50,000; four (10\%) earn above K50, 000. It is clear from the results that the income levels of Vikwa Telecentre users are very low. This might be attributed to the fact that the majority of the respondents, as indicated above, are students and that most Malawians live below the poverty line (Isaacs, 2007). The results in this section agree with earlier studies on telecentre usage that telecentres are used by those with low income levels (Neville, 2012; Chigona et al., 2011; Dahalin et al., 2009). On the other hand, the results differ from the findings of a study conducted by Kumar and Best (2007) which found that most telecentres users have high incomes. Therefore, understanding telecentre usage in every context is important.

\section{Duration (length of time) and frequency of using the telecentre}

Telecentre users were asked to indicate when they started using the telecentre as literature shows that telecentres are mostly used by the same people (Kapondera \& Hart, 2016; Etta \& Parvyn-Wamahiu, 2003) thereby questioning the role of telecentres in development. From the results shown in Table 3 , the telecentre is receiving new users almost each year. Although this is encouraging to the telecentre management staff, the number of people joining the telecentre as users sometimes drops in some years.

Table 3 Users' period and frequency of using the Telecentre 


\begin{tabular}{|c|c|c|c|}
\hline \multirow{8}{*}{$\begin{array}{l}\text { Yearear in which users } \\
\text { started using Vikwa } \\
\text { Telecentre }\end{array}$} & 2010 & 6 & 17 \\
\hline & 2011 & 2 & 6 \\
\hline & 2012 & 5 & 9 \\
\hline & 2013 & 3 & 8 \\
\hline & 2014 & 1 & 2 \\
\hline & 2015 & 17 & 47 \\
\hline & 2016 & 2 & 6 \\
\hline & Total & 36 & 100 \\
\hline \multicolumn{4}{|c|}{ Table 3B: Frequency of using the Telecentre } \\
\hline \multirow{8}{*}{$\begin{array}{l}\text { Frequency of telecentre } \\
\text { use }\end{array}$} & More than once a day & 6 & 14 \\
\hline & Once a day & 17 & 39 \\
\hline & Twice a week & 10 & 23 \\
\hline & Once a week & 5 & 11 \\
\hline & Once a month & 1 & 2 \\
\hline & Every three months & 1 & 2 \\
\hline & Rarely & 4 & 9 \\
\hline & Total & 44 & 100 \\
\hline
\end{tabular}

We also aimed at finding out how often people use the Telecentre as literature showed that users visit the telecentres every day (Etta \& Parvyn-Wamahiu, 2003). Results in Table 3 show that more than half of the respondents $(23.52 \%)$ visit the telecentre at least once a day. The results in this section imply that the Telecentre is mostly used by the same people thereby confirming the trend in literature. Observation during the data collection period also confirmed this as most users were seen visiting the telecentre daily.

\section{Purpose for using Vikwa Telecentre}

This section examined what Vikwa Telecentre is used for. Table 4 shows that a majority of people $30(65 \%)$ use the telecentre to complete school assignments. This might be attributed to the fact that most users are students. Field notes recorded through observations also indicated that most users were seen studying and writing assignments. This was followed by 13 people who indicated that they come to the telecentre to improve work related skills; 12 who indicated that they like to keep in touch with family and friends; 11 who reported that they look for jobs; while 10 indicated that they connect with colleges and/or universities respectively. These results agree with the findings of other studies (for example, Chigona, et al., 2011). Although results in section 5.1.1 show that a good number of users indicated to be business personnel 13(32\%), the findings on the purposes of using the telecentre indicate that only a few $3(7 \%)$ used the telecentre for business purposes. Although literature shows that telecentres help farmers to increase their incomes through communicating with buyers (Kenny 2002), this study established that only $2(4 \%)$ used the telecentre to communicate with buyers. The 
difference could be attributed to the fact that only $3(7 \%)$ of the respondents indicated that they were farmers.

Table 4: Purpose for using Vikwa Telecentre

$\mathrm{N}=46$

\begin{tabular}{|l|l|l|l|}
\hline S/N & Purpose & $\begin{array}{l}\text { Response } \\
\text { s }\end{array}$ & Percentage \\
\hline 1 & To complete school assignments & 30 & 65 \\
\hline 2 & To improve work related skills fachilies & 13 & 28 \\
\hline 3 & Keep in touch with friends and familes & 12 & 26 \\
\hline 4 & To look for jobs & 11 & 24 \\
\hline 5 & To connect with colleges and or universities & 10 & 22 \\
\hline 6 & To communicate with colleagues & 8 & 17 \\
\hline 7 & To communicate with tourists farms or & 3 & 13 \\
\hline 8 & To find a relationship/partner from farming & 3 & 7 \\
\hline 9 & $\begin{array}{l}\text { To increase earnings from } \\
\text { businesses }\end{array}$ & 2 & 4 \\
\hline 10 & $\begin{array}{l}\text { To communicate with buyers or sellers } \\
\text { online }\end{array}$ & \\
\hline
\end{tabular}

${ }^{*}$ Multiple responses received

\section{Benefits of Vikwa Telecentre}

The purpose of this section was to find out the benefits of Vikwa Telecentre to the community. This was determined by finding out how the telecentre has helped people and the changes that users have experienced since they started using the telecentre.

Users were asked to indicate how the telecentre has helped them. Table 5 below depicts the results. From the Table, majority 33 (72\%) indicated that it has helped them improve their performance in school. This could be attributed to the fact that, as shown in section 5.1.1, majority of users $22(52 \%)$ were students. This was followed by 24 (52\%) and 18 (39\%) who indicated that the telecentre has helped them acquire computer skills and meet new people respectively. Those who selected the 'other' option indicated that the telecentre has improved their knowledge; and that it has helped them save money spent on accessing the services. The results in this section to a large extent reflect the findings on the uses and occupation of the telecentre in which it was found out that education (30) and increasing social interaction (12) were among the main purposes for using the telecentre.

Table 5: How Vikwa Telecentre has helped its users $\mathrm{N}=46$

\begin{tabular}{|l|l|l|l|}
\hline S/N & benefit & $\begin{array}{l}\text { Respons } \\
\text { es }\end{array}$ & Percentage \\
\hline 1 & $\begin{array}{l}\text { It has helped me to improve performance in } \\
\text { school }\end{array}$ & 33 \\
\hline 2 & It has helped me to acquire computer skills & 24 & 52 \\
\hline 3 & It has helped me meet new people & 18 & 39 \\
\hline 4 & It has helped me to have more friends & 12 & 26 \\
\hline
\end{tabular}




\begin{tabular}{|l|l|l|l|}
\hline 5 & $\begin{array}{l}\text { It has helped me find the job through reading } \\
\text { newspapers }\end{array}$ & 7 & 15 \\
\hline 6 & $\begin{array}{l}\text { It has helped me to find agricultural information } \\
\text { which has improved my farming business }\end{array}$ & 4 & 9 \\
\hline 7 & It has helped me to have more money & 3 & 7 \\
\hline 8 & Other (Specify) & 3 & 7 \\
\hline
\end{tabular}

${ }^{*}$ Multiple responses allowed

Interviews with the telecentre Manager also agreed with the results. In the extract from the interview transcript below, the Manager claimed that the telecentre, through its library, is helping students improve their performance:

Their [students'] performance improves when they study here [in the library]. I feel like we are helping a lot to develop the community." Telecentre Manager.

Although the telecentre manager was not asked to give statics of the pass rate before and after the telecentre establishment, responses from the users, especially students in an open-ended question indicated that the telecentre helps the students improve their performance. Some users said:

"It has helped me to improve performance in school" QR30

"I used to fail in class but now my life has changed" QR41

The Telecentre Manager also argued that the telecentre has helped users acquire computer skills. According to him, these skills have helped users to find jobs and start businesses. Thus, he commented:

It has been very useful. According to my experience as a Telecentre Manager, I have been seeing people finding good jobs because they have been trained here in computer basics. So, we have a good number of products from this institution.... most people who come here or used to come here are working as clerks and use computers. So, many are .....who use the computers. Yeah, so they end up working as clerks and they get the knowledge in Excel and Word here. We always train people to establish their own business. So, it has been a very beneficial institution to many people....

\section{Changes that telecentre users have experienced}

All the 46 respondents claimed to have experienced changes. They were then asked in an open-ended question to explain the changes they have experienced. Some of their responses are presented in Table 4 below. Most of these have to do with improving the skills and knowledge of users through computer training programmes and through reading library materials; improving students' performance; 
helping people expand their social networks; making communication easy and helping people save money by providing cheaper ICT services.

\section{Table 4: Changes that Vikwa Telecentre users have experienced}

\begin{tabular}{|c|c|}
\hline $\begin{array}{l}\text { Units of } \\
\text { meaning }\end{array}$ & Selected quotations \\
\hline $\begin{array}{l}\text { Improving skills } \\
\text { and knowledge }\end{array}$ & $\begin{array}{l}\text { - I have really improved computer skills QR16 } \\
\text { - I have learnt a lot through reading QR18 } \\
\text { - It has helped me to improve performance in school QR30 } \\
\text { - I have indicated that my life has changed because I have } \\
\text { been helped quiet a lot because I read in the library, find } \\
\text { jobs easily and have learnt different skills through } \\
\text { computer QR } 28 \\
\text { - I have improved my English speaking through reading } \\
\text { newspapers and my performance in class am now } \\
\text { able to capture things well QR36 } \\
\text { - It has helped me improve my performance at school as it } \\
\text { offers me a conducive environment for reading QR39 } \\
\text { - Because I know a lot of things through the Internet QR42 } \\
\text { Previously, I did not know how to use the computer } \\
\text { but I now know QR45 }\end{array}$ \\
\hline $\begin{array}{l}\text { Improved } \\
\text { communication } \\
\text { and friendships }\end{array}$ & $\begin{array}{l}\text { - Communication is easy QR32 } \\
\text { - I have known many people through the use of this } \\
\text { Telecentre QR14 }\end{array}$ \\
\hline Saving money & - Provides cheaper services than other Cybercafes QR31 \\
\hline
\end{tabular}

\section{Challenges that telecentre users face}

Despite the benefits that telecentre users are enjoying, they also meet challenges in using the telecentre. Table 5 below depicts the results on the challenges that users face. These include: inadequate facilities 22 (48\%), slow internet connection 18 (39\%), and high cost for some services $16(35 \%)$. Although users were not asked what they meant by saying inadequate facilities, their comments in an open-ended question on the topic indicated that computers and library books are the things deemed to be not enough. The following are some of the comments made by some users:

"The books used for learning computers are insufficient" QR3

"There are few books in the library and most of them are outdated" QR12

Our infrastructure audit revealed that the telecentre had 12 computers: 10 or users and two for staff. This could be perceived as not being enough especially for computer tutorial sessions when according to the Telecentre Manager, the more than 10 users attend at once. The 
unreliability of the internet is also a challenge to the users as its slowness usually hampers the progress of the users as one of them reported:

\section{"Because of slow Internet I don't finish my work" QR20.}

Observations also confirmed the challenge on internet connection. During the period of data collection, the Internet was completely not available. This had been a situation for a year and that the Internet Service Provider, Malawi Telecommunications Limited was working on fixing it. Further interviews indicated that, as a temporary measure, the Telecentre Manager bought two internet dongles and uses his mobile phone as a hotspot so that that users could still have access to Internet.

Respondents also indicated that the other challenge was the cost. It was indicated that some services offered are expensive. This might be attributed to the fact the rural communities in Malawi are poor (Isaacs 2007); and that the income levels of the majority of users as depicted in demographic section above are low with 52\% earning less than $\$ 7.07$ a month. The results in this section are in line with several studies in literature (for example, Mtega \& Malekani, 2009; Hassan et al., 2010; Buhigiro, 2012) that poverty affects the usage of telecentres in rural communities.

Table 5: Challenges that Vikwa Telecentre users face $\quad \mathrm{N}=46$

\begin{tabular}{|l|l|l|l|}
\hline $\begin{array}{l}\text { S/ } \\
\mathbf{N}\end{array}$ & Challenge & $\begin{array}{l}\text { Response } \\
\text { s }\end{array}$ & $\begin{array}{l}\text { Percentag } \\
\text { e }\end{array}$ \\
\hline 1 & Inadequate physical facilities & 22 & 48 \\
\hline 2 & Slow Internet connection & 18 & 39 \\
\hline 3 & High costs for some services & 16 & 35 \\
\hline 4 & It is too crowded & 12 & 26 \\
\hline 5 & Lack of Internet searching skills & 10 & 22 \\
\hline 6 & Lack of information in local language & 8 & 17 \\
\hline 7 & Lack of support when using the telecentre & 7 & 15 \\
\hline 8 & Shortage of opening hours & 5 & 11 \\
\hline 9 & Poor staff attitude towards users & 2 & 4 \\
\hline & *Multiple responses allowed & & \\
\hline
\end{tabular}

The last question in the questionnaire asked users to provide any comment on how they perceived the telecentre.. Table 6 below depicts the responses, which have been classified into six key themes

- The telecentre is relevant to the community: the telecentre is being perceived relevant in the community because, among others, it is equipping users with computer and Internet skills; and that it is helping people find jobs.

- Insufficient facilities: it seems users need more facilities and services in the centre. Some users gave examples of books and computers being insufficient. 
- Slow internet connection: some comments indicated that internet is very slow. This negatively impacts on users' work because sometimes they do not finish their work.

- Cost of services: users complained that computer services were expensive.

- Staff attitude: some users indicated that some telecentre staff lacked customer care skills.

- $\quad$ Alternative power supply needed: The telecentre only relies on power supplied by Electricity Supply Corporation of Malawi (ESCOM), which is not reliable. Sometimes the telecentre experiences five hours of power outage and this disrupts its operations.

Table 6: Themes identified from comments in the questionnaire

\begin{tabular}{|c|c|}
\hline $\begin{array}{l}\text { Units of } \\
\text { meaning }\end{array}$ & Selected quotations \\
\hline $\begin{array}{l}\text { Insufficient } \\
\text { facilities or } \\
\text { resources }\end{array}$ & $\begin{array}{l}\text { - We need a lot of facilities QR29 } \\
\text { - It lacks resources e.g. ink for printers QR14 } \\
\text { - The books used when learning computers } \\
\text { are insufficient QR3 } \\
\text { - There are few books in the library and most } \\
\text { of them are outdated QR12 }\end{array}$ \\
\hline $\begin{array}{l}\text { Slow internet } \\
\text { connection }\end{array}$ & $\begin{array}{l}\text { - Because of slow Internet I don't finish my } \\
\text { work QR20 }\end{array}$ \\
\hline $\begin{array}{l}\text { The telecentre is } \\
\text { beneficial to the } \\
\text { community }\end{array}$ & $\begin{array}{l}\text { - I do appreciate the development of this } \\
\text { telecentre in our community since it has } \\
\text { improved our skills QR7 } \\
\text { - The telecentre is very important for us to } \\
\text { learn internet QR28 } \\
\text { - We thank God for giving us this telecentre } \\
\text { which has developed our community by } \\
\text { equipping people in the community with } \\
\text { internet skills QR27 } \\
\text { - It has helped the community with job } \\
\text { opportunities QR18 } \\
\text { Telecentre provides education through } \\
\text { teaching people how to use computers QR15 }\end{array}$ \\
\hline $\begin{array}{l}\text { Some services } \\
\text { are expensive }\end{array}$ & - The use of computers is expensive QR2 \\
\hline $\begin{array}{l}\text { Some staff have } \\
\text { poor attitude }\end{array}$ & $\begin{array}{l}\text { - Some workers do not have customer care } \\
\text { QR35 } \\
\text { - Those working in the telecentre should be } \\
\text { dedicated QR42 }\end{array}$ \\
\hline $\begin{array}{l}\text { Alternative } \\
\text { power source } \\
\text { needed }\end{array}$ & $\begin{array}{l}\text { - Source of power-hydro-electric power } \\
\text { ESCOM needs alternative source like solar } \\
\text { power energy QR21 }\end{array}$ \\
\hline
\end{tabular}

\section{Summary and recommendations}


The study examined the uses, benefits and challenges of using multipurpose community telecentres in Malawi as tools for development by targeting the Vikwa Community Telecentre. From the findings, then users were generally males, youths, less educated, students and having low income levels. The main purpose of using the telecentre is to complete assignments. Other users also use the telecentre to improve work related skills, keep in touch with friends and families, and look for jobs. It can also be concluded that users are benefiting a lot from the use of the telecentre as they have experienced a number of changes in their lives. The main changes include: improving skills and knowledge, improving performance in school, finding new friends and saving money because the services are nearer and cheaper.

Despite the benefits, the users face a number of challenges when using the telecentre. Some of these challenges are slow and unavailability of Internet connection; inadequate computers and books in the library; some services are expensive; frequent blackouts; and that some telecentre staff lack customer care skills. The study recommends the following:

- The telecentre should look for an alternative power supply such as buying a generator

- The telecentre Management should offer training on customer care services to its staff.

- The telecentre should acquire more computers and add more books in the library

- On internet connection, the telecentre should change Internet Service Provider

- Government should formulate deliberate policies to support the growth and use of telecentres by, among others, subsidizing the cost of using facilities at the telecentres, enabling them to offer certificates (recognized qualifications) to people who learn computer skills from the facilities.

- The Telecentre management should extend its user base.

- There is need to encourage women to use telecentres.

\section{Benefits and contributions of the Study}

The study is important to the Vikwa Telecentre management and Malawi Government which establishes telecentres in the country. Hopefully, the findings of the study will help the telecentre on how best to attract all groups of people in the community; and deal with the challenges so that the telecentre effectively contributes towards the development of the community. In addition, the study contributes towards generating information aimed at helping ICT policy makers regarding the usage and challenges as tools for development in rural areas in Malawi. It also contributes on literature of uses, benefits and challenges of using telecentres as tools for development. 


\section{References}

Ariyabandu, R. (2009).

Role of telecentres as knowledge networks: successes and challenges.

http://ictlogy.net/bibliography/reports/projects.php?idp=2212 . (Accessed 5 June 2016)

Bailey, A. (2009).

Issues affecting the social sustainability of telecentres in developing contexts: A field study of sixteen telecentres in Jamaica. The Electronic Journal of Information Systems in Developing Countries, $36(4):, 1-18$.

Banda, G.C. (2016).

Personal communication. 10 January 2016.

Braun, V. \& Clarke V. (2006.)

Using thematic analysis in psychology. Qualitative Research in Psychology, 3(2), 77-101.

Buhigiro, S. (2012).

The role of telecentres in promoting socio-economic development in Rwanda. Master of ????? thesis. University of the Witwatersrand.http://hdl.handle.net/10539/12464. (Accessed 20 September, 2016).

Chikumba, P. A. (2010).

Utilization of ICTs in multipurpose community telecentres in rural Malawi. In Popescu-Zeletin, R., Rai, I.A., Jonas, K. \& Villafiorita, A. (Eds). E-Infrastuctures and E-Services for Developing Countries: 93-101. New York: Springer.

Chigona, W., Lekwane, O., Westcott, K. \& Chigona, A.(2011).

Uses, benefits and challenges of public access points in the face of growth of mobile technology. The Electronic Journal of Information Systems in Developing Countries, 49(5),1-14.

Creswell, J.W. (2003).

Research design: Qualitative, Quantitative and Mixed Methods Approaches. (2nd edition). Thousand Oaks: Sage publications.

Dahalin, M. Z., Yusop, N.I., Ibrahim, H., Kasiran, M.K. and Mat A., Z., (2009).

Socio-economic benefits of telecentre implementation in Peninsular Malaysia. International Conference on Computing and Informatics 2009 (ICOCI09).

DeWalt, K. M. \& DeWalt, B. R. (2002).

Participant observation: a guide for fieldworkers. Walnut Creek.CA: AltaMira Press.

Etta, F. E. \& Parvyn-Wamahiu, S. (Eds.). (2003).

Information and communication technologies for development, volume 2: the experience with community telecentre. Ottawa: International Development Research Centre. 
Fowler, F. J. (2009).

Survey research methods. 4th ed. London: SAGE Publications.

Guarte, J. M., \& Barrios, E. B. (2006).

Estimation under purposive sampling. Communications in Statistics - Simulation and Computation, 35(2), 277-284.

Garrido, M., Sey, A., Hart, T., \& Santana, L. (2012).

Literature review of how telecentres operate and have an impact on einclusion.

European

Union.

https:/ / dlib.lib.washington.edu/researchworks/handle/1773/20

955 (Accessed 19 August 2016)

Gcora, N., Gopeni, A., Tuswa, M., Lwoga, E. T., \& Chigona, W. (2015).

The challenges rural women face in using Telecentres: The case of the Eastern Cape Province. 9th IDIA conference. http://ir.muhas.ac.tz:8080/jspui/handle/123456789/2001.

(Accessed 15 May 2016)

Gondwe, G. (2008).

Malawi's Rural ICT Initiative on

Course.http://unpan1.un.org/intradoc/groups/public/docume nts/cpsi/unpan035113.pdf. Accessed 20 April 2016)

Harris, R. (2001).

Telecentres in rural Asia: towards a success model. Europe, 40 (23):71-111.

Harris, R. W., Kumar, A., \& Balaji, V. (2003).

Sustainable telecentres? Two cases from India. The digital challenge:

Information technology in the development context, 8:124-135.

Hassan, S., Yusof, Y., Seman, M. A. A., \& Sheik, W. R. (2010).

Impact Analysis on Utilization of Telecenter: The Case of

Telecenter in Baling.

http:/ / www.kmice.cms.net.my/prockmice/kmice2010/Paper/P

G14_19.pdf. (Accessed 15 August 2016).

Human Development Report. (2015).

Human Development Report 2015: Work for human development. New

York: United Nations Development Programme.

IFAD (2017).

Investing in rural people in

Malawi.https://www.ifad.org/documents/10180/c31ccb11-f0e5-

4b56-b0ef-0bd74f1e6e79. (Accessed 10 May 2017)

Isaacs, S. (2007).

Survey of ICT and education in Africa: Malawi country report. http://www.infodev.org/infodev-

files/resource/InfodevDocuments_414.pdf. $\quad$ (Accessed 10

November 2016).

Islam, S., \& Hasan, N. (2009).

Multipurpose community telecentres in Bangladesh: problems and prospects. The electronic library, 27(3), 537-553.

Jensen, M. \& Esterhuysen, A. (2001). 
The community telecenter cookbook for Africa, recipes for self sustainability: how to establish a multipurpose community telecenter in Africa. Paris: UNESCO.

Kapondera, S.K. \& Hart, G. (2016).

The use of multipurpose community telecentres and their services in Malawi. The case of Lupaso Community Telecentre, the South African Journal of Libraries and Information Science, 82(1): 1325.

Kawulich, B. B. (2005).

Participant observation as a data collection method. In Forum Qualitative Sozialforschung/Forum: Qualitative Social Research,6(2),http: / / www.qualitativeresearch.net/index.php/fqs/article/view/466/996. (Accessed 15 November, 2016)

Kenny, C. (2002).

The costs and benefits of ICTs for direct poverty alleviation. World Bank: Washington, DC, borrador Enero, 22.. http:/ / citeseerx.ist.psu.edu/viewdoc/download?doi=10.1.1.15.34

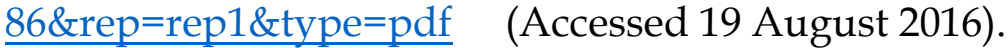

Kumar, R. \& Best, M. L. (2007).

Social impact and diffusion of telecentre use: a study from the Sustainable Access in Rural India Project. The Journal of Community Informatics,2(3).http:/ / cijournal.net/index.php/ciej/article/viewArticle/328.(Accessed 10 May 2016)

Lashgarara, F., Karimi, A., \& Mirdamadi, S. M. (2012).

Effective factors on the villagers use of rural telecentres (case study of Hamadan province, Iran). African Journal of Agricultural Research, 7(13), 2034-2041.

Lwoga, E. T., \& Chigona, W. (2016).

Characteristics and factors that differentiate Internet users and non-users as information seekers: The case of rural women in Tanzania. Information Development, http://journals.sagepub.com/doi/pdf/10.1177/026666691666955 7. Accessed 11 May 2017).

Malawi Government. (2014).

2014 Millennium Development Goals report for Malawi.http://www.undp.org/content/dam/malawi/docs/gen eral/Malawi_MDG_Report_2014.pdf. (Accessed 15 March 2017).

Malawi Communication Regulatory Authority. (2015).

National survey on access to and usage of ICT services in Malawi.

Blantyre: MACRA.

http://www.macra.org.mw/wpcontent/uploads/2016/01/MACRA-Survey-Report-National- 
Household-and-Individual-access-to-and-usage-of-ICT.pdf.

(Accessed 5 November 2016).

Mathers, N. Fox N., \& Hunn, A. (2007).

Surveys and Questionnaires. The NIHR RDS for the East

Midlands: Yorkshire \& the Humber.

Mbangala, B., \& Samzugi, A. (2014).

The Role of Telecentres in Tanzania's Rural Development. A

Case Study of Sengerema District Council, Mwanza Region.

Library Philosophy and Practice.

http://digitalcommons.unl.edu/libphilprac/1224/. (Accessed 10 June 2016)

Mbatha, B. (2015).

Diffusion and adoption of information and communication technologies in South African telecentres: selected telecentres in Kwazulu-Natal. Mousaion, 33(1), 103-120.

Mtega, W. \& Malekani, A. (2009).

Analyzing the usage patterns and challenges of telecentres among rural communities: experience from four selected telecenters in Tanzania. International Journal of Education and Development Using ICT, 5(2):68-87

Mukerji, M. (2008).

Access, Use and Impact of Rural Telecentres: Findings from a Village-Level Exploration.

Mwiinga, T.M. \& Hamooya, C. (2016).

An investigation on the usage of Web 2.0 applications for educational purposes among undergraduate students at University of Zambia. In Proceedings of the Standing Conference of the Eastern, Central and Southern Africa Librarians and Institutions, Swaziland. 187-192

Neville, K. (2012).

Libraries, Telecenters, Cybercafes and Public Access to ICT: International Comparisons. Ed. by Ricardo Gomez. Hershey, PA: IGI Global/Information Science Reference, 2012. The Australian Library Journal, 61(4), 321-322

Njinga, W. (2016).

Personal communication. 14 February, 2016.

Kayira, T. (2013).

Challenges in Promotion of Universal ICT Access and Services in Rural Malawi. In CPRsouth8/CPRafrica2013 conference.https:// papers.ssrn.com/sol3/papers.cfm?abstract_id= 2363871. (Accessed 20 December 2015).

Onwuezbuzie, A. J. \& Johnson, R. B. (2006).

The validity issue in mixed research. Research in the Schools, 13 (1):48-63.

Owen Jr, W., \& Darkwa, O. (2000). 
Role of multipurpose community telecentres in accelerating national development in Ghana. First Monday, 5(1). http://journals.uic.edu/ojs/index.php/fm/article/view/722/63 1. (Accessed 10 January 2016).

Reja, U., Manfreda, K. L., Hlebec, V., \& Vehovar, V. (2003).

Open-ended vs. close-ended questions in web questionnaires. Developments in applied statistics, 19, 159-177. https://papers.ssrn.com/sol3/papers.cfm?abstract_id=2363871 (Accessed 8 December 2015).

Rose, J. B. (1999).

Multipurpose community telecentres in support of people-centred development. Information technology and globalisation: implication for people-centred development. SFI Publishing, London.

Taulo, J., Gondwe, K., \& Sebitosi, A. (2015).

Energy supply in Malawi: Options and issues. Journal of Energy in Southern Africa, 26(2), 19 - 32.

Soriano, C. R. R. (2007).

Exploring the ICT and rural poverty reduction link: community telecentres and rural livelihoods in Wu'an, China. The Electronic Journal of Information Systems in Developing Countries, 3 2.http://www.ejisdc.org/ojs2.../index.php/ejisdc/article/view/ 462/0. (Accessed 20 January 2016).

Warschauer, M. (2003).

Technology and Social Inclusion: Rethinking the Digital Divide.

Cambridge; Massachusetts Institute of Technology Press. 